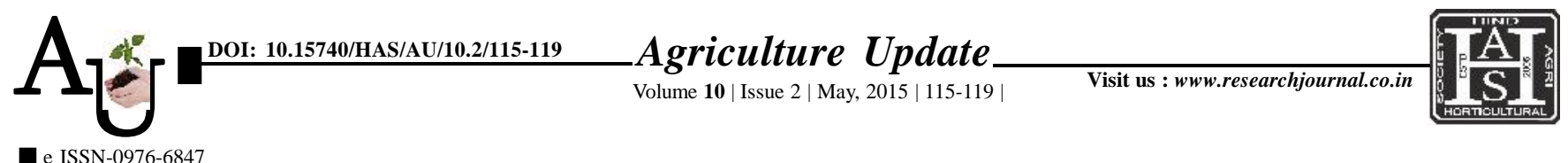

\title{
Research article: Contract farming in sweet corn - a new dimension for tribal farmers of Navsari district
}

Article Chronicle: Received :

01.03.2015;

Revised :

12.03.2015;

Accepted :

28.03.2015

KeY WordS:

Contract farming, KVK, Intervention, Sweet corn
Author for correspondence :

\section{B.M. TANDEL}

Krishi Vigyan Kendra

(N.A.U.), NAVSARI

(GUJARAT) INDIA

Email: hariombhupi@

gmail.com

See end of the article for

authors' affiliations

\section{B.M. TANDEL*, K.A. SHAH AND PRABHU NAYAKA}

SUMMARY : The study was conducted in tribal dominated Navsari district. A total number of 160 tribal farmers from 16 villages were selected purposively and from each village 10 respondents were selected. The study focused on the economics of contract farming of sweet corn in South Gujarat and its impact on income, employment and access to technology and credit by contact farmers. The study revealed that a clear majority of the respondents $(52 \%)$ had medium level of knowledge. Their adoption level was predominately medium level $(51 \%)$. After KVK intervention overall income of respondents has been increased to 41 per cent.

How to cite this article : Tandel, B.M., Shah, K.A. and Nayaka, Prabhu (2015). Contract farming in sweet corn - a new dimension for tribal farmers of Navsari district. Agric. Update, 10(2): 115-119. 